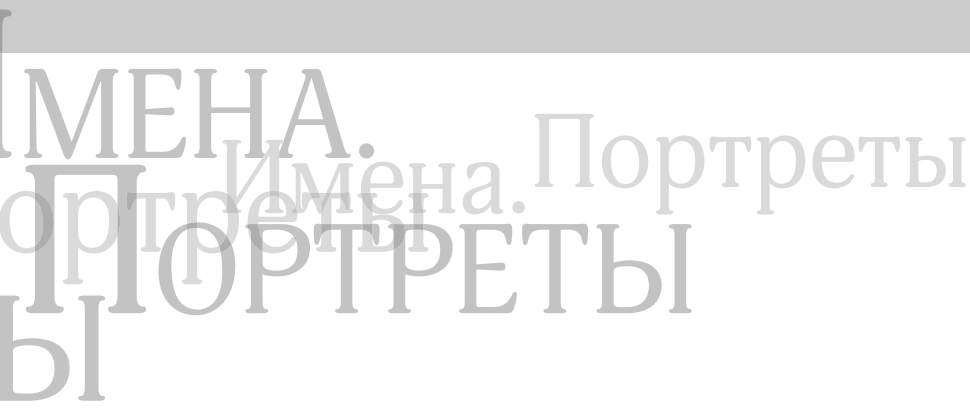

ИMEHА. ПОРТРЕТЫ

УДК 78.071.1

ББК $85.313(2) 52$

\title{
A.E. МАКСИМОBA
}

\section{РУССКИЙ СЮЖЕТ \\ В БАЛЕТНОМ ТВОРЧЕСТВЕ КАТЕРИНО КАВОСА*}

\section{Александра Евгеньевна Максимова,}

Московская государственная консерватория

им. П.И. Чайковского,

кафедра истории русской музыки,

доцент

Большая Никитская ул., д. 13/6, Москва, 125009, Россия

кандидат искусствоведения, доцент

E-mail: alexmaximova@mail.ru

Реферат. Статья посвящена балетным произведениям итальянского композитора К.А. Кавоса, написанным в России. Свыше 50 театральных сочинений композитора почти неизвестны, при этом составляют существенный вклад в отечественную культуру. Исследование проведено на основе неизданных источников из архивов Москвы и Санкт-Петербур2а. Прослеживается история национальных сюжетов русского музыкального профессионального театра со времен Екатерины II до первой четверти ХІХ столетия. Рассмотрена проблема «русского» сюжета в операх, балетах, драматических пьесах с музыкой Кавоса, создан перечень этих сочинений. Выявлено, что постоянными соавторами композитора были писатель А.А. Шаховской и балетмейстер Ш. Дидло. В обозрение вошли исторические, бытовые, сказочно-волшебные сюжеты. Отмечены стилевые особенности произведений (в том числе их опора на фольклорный материал) на примере балетов-дивертисментов «Ополчение, или Любовь к Отечеству», «Сельский праздник», музыки к драме А.А. Шаховского «Сокол князя Ярослава Тверского, или Суженый на белом коне».

Ключевые слова: Россия, К.А. Кавос, история, театр, балет, дивертисмент, опера, драма, музыка, фольклор.

Для цитирования: Максимова А.Е. Русский сюжет в балетном творчестве Катерино Кавоса // Обсерватория культуры. 2017. Т. 14, № 2. С. 198-207.

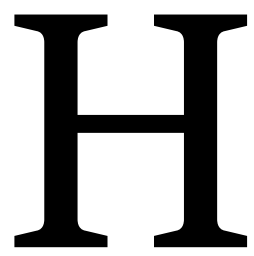

ациональный сюжет в русском музыкальном театре берет свои истоки от последней четверти XVIII в. и напрямую связан с творчеством Екатерины II. Императрица, как известно, занималась литературной деятельностью, в том числе сочиняла драматические пьесы и оперные либретто. Она впервые вводит в театральный обиход темы, обращенные к русскому фольклору и истории. С 1786 до 1791 г. появляются ее либретто комических опер со сказочным сюжетом: «Февей», «Новгородский богатырь Боеславич», «Храбрый и смелый витязь Ахридеич» (1786), «Горе-богатырь Косометович» (1789), «Федул с детьми» (1791). К 1786 г. относит-

${ }^{*}$ Исследование выполнено при финансовой поддержке Российского фонда фундаментальных исследований (РФФИ) в рамках научного проекта № 16-0400473. 
ся создание трилогии «исторических представлений», созданной на основе хроник древней русской истории: «Подражание Шекспиру, историческое представление без сохранения театральных обыкновенных правил, из жизни Рюрика», «Начальное управление Олега, подражание Шекспиру, без сохранения театральных обыкновенных правил» и «Игорь» (не окончена) ${ }^{1}$. Пьесы трилогии написаны без соблюдения правил классицизма - единства места, времени и действия. Драматическое действие этих пьес сочеталось с музыкальным оформлением и балетными сценами. Итак, в творчестве Екатерины II складываются новые, национально окрашенные, литературно-театральные направления - сказочное и историческое. Безусловно, привлечение русских источников в литературу происходило в рамках внутренней государственной политики по укреплению патриотизма в обществе.

Музыку к спектаклям Екатерины II писали придворные композиторы, как правило, иностранного происхождения. Например, партитура оперы «Храбрый и смелый витязь Ахридеич» принадлежала чешскому композитору Э. Ванжуре [1], музыкальные номера к «Начальному управлению Олега» [2, c. 7-22] сочинили итальянцы Дж. Сарти и К. Каноббио совместно с В.А. Пашкевичем ${ }^{2}$. Итальянский композитор испанского происхождения В. Мартини-Солер стал автором опер «Горе-богатырь Косометович» и «Федул с детьми» (последняя совместно с В.А. Пашкевичем $)^{3}$.

Контракты, заключенные приезжими композиторами с Дирекцией императорских театров, обязывали их сочинять «российские» оперы, балеты и музыку к драме. Русским языком никто из них не владел, а осведомленность о фольклорной музыке была весьма ограниченной ${ }^{4}$. Одним из важнейших средств выражения национального колорита в музыке становится цитирование народных тек-

${ }^{1}$ Литературные произведения Екатерины неоднократно издавались в XIX в.: под редакцией А. Смирдина (1849), В.Ф. Солнцева и А.И. Введенского (1893), Я. Соколова (1895). Полное собрание сочинений Екатерины в 12 томах издано Академией наук в 1901-1908 гг. под редакцией А.Н. Пыпина и Я.Л. Барскова. В публикацию вошли впервые издаваемые сочинения и автобиографические заметки Екатерины II.

2 «Подражание Шакеспиру без сохранения феатральных обыкновенных правил. Российское историческое представление в 5-ти д. Екатерины II с хорами и балетами». Муз. К.А. Каноббио, В.А. Пашкевича, Дж. Сарти. Балет «на греческом ипподроме» Дж. Канциани, отдельные танцы Ш. Ле Пика. Исполнители: В.М. Балашов, В. Гладышев и др. Петербург, Эрмитажный театр, 1790.

${ }^{3}$ Долгое время считалось, что Екатерина II является автором либретто оперы В. Мартина-и-Солера «Песнолюбие» (1790), в действительности либретто принадлежит ее статс-секретарю А.В. Храповицкому.

${ }^{4}$ Для понимания взгляда иностранных музыкантов XVIII в. на русский фольклор, достаточно ознакомиться с книгой: [3, c. 62-67]. стов и мелодий. Вспомогательным материалом для композиторов стали сборники народных песен ${ }^{5}$, выпущенные при поддержке Кабинета императрицы.

С апреля 1799 г. должность придворного капельмейстера и композитора Императорских театров занимает итальянский композитор Катерино Альбертович Кавос (1775-1840). Согласно контракту он обязался «сочинять все российские оперы и балеты, какие мне от дирекции поручены будут» [4, с. 126]. Будучи весьма незаурядной личностью, Кавос проработал в России свыше 40 лет и внес неоценимый вклад в русскую музыкальную культуру.

Композиторское творчество К.А. Кавоса охватывает более 50 театральных произведений, среди которых оперы, балеты, балеты-дивертисменты, музыка к драматическим спектаклям и водевилям. Большинство сочинений хранятся в рукописях и не изданы.

В 1803 г. Кавос принял на себя руководство русской оперной труппой и воспитал целую плеяду театральных певцов (в их числе П.В. Злов, Г.Ф. Климовский (Иваницкий), В.С. Самойлова (Черникова), Е.С. Сандунова, О.А. Петров, А.Я. Воробьева-Петрова). Для молодого русского театра, сформировавшегося в екатерининский период, композитор написал целый ряд произведений, основанных на национальных сюжетах или созданных на либретто отечественных авторов. Среди его трудов балеты и балеты-дивертисменты, а также балетные сцены в операх и драматических спектаклях. Приведем список этих сочинений, собранный нами из различных источников и расположенный в хронологическом порядке их сценических воплощений (см. табл. 1) [5; 6].

Представленные сочинения написаны на исторический (нередко с привлечением патриотической тематики), сказочно-волшебный и бытовой сюжеты. Остановим свое внимание на нескольких из них.

Война 1812 г. спровоцировала рождение жанра национально-патриотического балета-дивертисмента на русской сцене. «Современность вторглась в балет», - пишет А.А. Гозенпуд об этом явлении [7, с. 350]. В период с 1810 г. появляются произведения, основанные на недавних исторических событиях, отражающие хронику военных походов. В сотрудничестве с хореографами И.И. Вальберхом, О. Пуаро, А.П. Глушковским, И.М. Аблецом и И.К. Лобановым Кавос работает над балетами

${ }^{5}$ См. «Собрание разных песен» М.Д. Чулкова (1770-1774), «Новое и полное собрание российских песен» Н.И. Новикова (1780-1781), «Собрание русских простых песен с нотами» В.Ф. Трутовского (1776-1795), «Собрание русских народных песен с их голосами...» Н.А. Львова и И.Г. Прача (1790), «Новый российский песенник» $(1790-1791)$, «Избранный песенник» (1792), «Российская Эрата» М.И. Попова (1792), «Карманный песенник» И.И. Дмитриева (1796), «Письмовник» Н.Г. Курганова (1796). 


\section{Сочинения К.А. Кавоса}

\begin{tabular}{|c|c|c|}
\hline № & Дата, место премьеры & Название, авторы \\
\hline \multicolumn{3}{|r|}{ Балет и дивертисмент } \\
\hline 1 & $\begin{array}{l}\text { 1812, } 30 \text { августа } \\
\text { СПб., Немецкий театр }\end{array}$ & $\begin{array}{l}\text { Ополчение, или Любовь к Отечеству. Балет в } 1 \text { д. с хорами и плясками. Хореогра- } \\
\text { фия И.И. Вальберха, О. Пуаро }\end{array}$ \\
\hline 2 & $\begin{array}{l}\text { 1813, } 19 \text { мая } \\
\text { СПб., Немецкий театр }\end{array}$ & $\begin{array}{l}\text { Русские в Германии, или Следствие Любви к Отечеству. Балет. Музыка А. Париса } \\
\text { и К.А. Кавоса. Хореография И.И. Вальберха, О. Пуаро }\end{array}$ \\
\hline 3 & $\begin{array}{l}\text { 1813, } 30 \text { августа } \\
\text { СПб., Немецкий театр }\end{array}$ & $\begin{array}{l}\text { Праздник в стане союзных армий при Монмартре. Дивертисмент, «торжественное } \\
\text { представление, составленное из танцев разных наций, эволюций и пения в честь } \\
\text { союзных армий». Текст П.А. Корсакова. Музыка К.А. Кавоса и Д.Н. Кашина. Хоре-- } \\
\text { графия И.И. Вальберха, О. Пуаро }\end{array}$ \\
\hline 4 & $\begin{array}{l}\text { 1813, } 3 \text { ноября } \\
\text { СПб., Немецкий театр }\end{array}$ & Казак в Лондоне. Балет-дивертисмент. Хореография И.И. Вальберха, О. Пуаро \\
\hline 5 & $\begin{array}{l}\text { 1814, } 3 \text { июня } \\
\text { СПб., Немецкий театр }\end{array}$ & $\begin{array}{l}\text { Торжество России, или Русские в Париже. «Аналогический балет с пением и хора- } \\
\text { ми», или: «аллегорико-исторический балет в } 3 \text { д.». Текст П.А. Корсакова. Хоре-- } \\
\text { графия И.И. Вальберха, О. Пуаро }\end{array}$ \\
\hline 6 & $\begin{array}{l}\text { 1814, } 15 \text { сентября } \\
\text { Москва, Театр Апраксина }\end{array}$ & $\begin{array}{l}\text { Праздник в стане союзных армий. Дивертисмент. Стихи П.А. Корсакова. Музыка } \\
\text { К.А. Кавоса и Д.Н. Кашина. Хореография И.М. Аблеца }\end{array}$ \\
\hline 7 & $\begin{array}{l}1814 \\
\text { Москва, Большой театр }\end{array}$ & Любовь к Отечеству. Пантомимный балет. Музыка К.А. Кавоса и Д.Н. Кашина \\
\hline 8 & $\begin{array}{l}\text { 1815, } 8 \text { января } \\
\text { Москва, Театр Апраксина }\end{array}$ & Праздник донских казаков. Дивертисмент. Хореография И.М. Аблеца \\
\hline 9 & $\begin{array}{l}\text { 1815, } 25 \text { января } \\
\text { Москва, Театр Апраксина }\end{array}$ & $\begin{array}{l}\text { Семик, или Гулянье в Марьиной роще. Дивертисмент. Хореограсрия И.М. Аблеца. } \\
\text { Музыка С.И. Давыдова и К.А. Кавоса }\end{array}$ \\
\hline 10 & $\begin{array}{l}\text { 1816, } 7 \text { января } \\
\text { Москва, Театр Апраксина }\end{array}$ & Масленица. Дивертисмент. Хореография И.М. Аблеца \\
\hline 11 & $\begin{array}{l}\text { 1817, } 5 \text { октября } \\
\text { Москва, Театр Апраксина }\end{array}$ & $\begin{array}{l}\text { Казаки на Рейне. Дивертисмент с хорами. Музыка Д.Н. Кашина, К.А. Кавоса } \\
\text { и И.А. Ленгарда. Хореография А.П. Глушковского }\end{array}$ \\
\hline 12 & $\begin{array}{l}\text { 1821, } 29 \text { января } \\
\text { СПб., Большой театр }\end{array}$ & Смотр невест, или Деревенские святки. Интермедия-дивертисмент \\
\hline 13 & $\begin{array}{l}\text { 1821, } 8 \text { декабря } \\
\text { Москва, Театр Пашкова }\end{array}$ & $\begin{array}{l}\text { Федул с детьми на ярмарке. Дивертисмент. Музыка Н.Е. Кубишты, К.А. Кавоса } \\
\text { и [?] Гирша. Хореограффия О. Пуаро, А.М. Сабурова }\end{array}$ \\
\hline 14 & $\begin{array}{l}\text { 1823, } 15 \text { января } \\
\text { СПб., Большой театр }\end{array}$ & $\begin{array}{l}\text { Кавказский пленник, или Тень невесты. «Древний национально-пантомимный ба- } \\
\text { лет» (по поэме А.С. Пушкина). Музыка К.А. Кавоса и Т.В. Жучковского. Хоре-- } \\
\text { графия Ш. Дидло }\end{array}$ \\
\hline
\end{tabular}




\begin{tabular}{|c|c|c|}
\hline № & Дата, место премьеры & Название, авторы \\
\hline 15 & $\begin{array}{l}\text { 1823, } 8 \text { июня } \\
\text { Москва, Театр Пашкова }\end{array}$ & $\begin{array}{l}\text { Русские в Германии, или Вечер на ярмарке. Дивертисмент. Музыка С.И. Давыдо- } \\
\text { ва и К.А. Кавоса. Хореография И. Лобанова }\end{array}$ \\
\hline 16 & $\begin{array}{l}\text { 1824, } 9 \text { октября } \\
\text { Москва, Театр Пашкова }\end{array}$ & $\begin{array}{l}\text { Праздник казаков на Дону. Дивертисмент. Музыка К.А. Кавоса, В. Кивакурцева } \\
\text { и [?] Лузина. Хореография И.К. Лобанова }\end{array}$ \\
\hline 17 & $\begin{array}{l}\text { 1825, } 29 \text { октября } \\
\text { СПб. }\end{array}$ & $\begin{array}{l}\text { Батюшкина дочка, или Нашла коса на камень. Комедия-балет. Текст А.А. Шахов- } \\
\text { ского. Музыка К.А. Кавоса, Д.А. Шелихова и П.Ф. Турика. Хореография Ш. Дидло }\end{array}$ \\
\hline 18 & $\begin{array}{l}\text { 1826, } 26 \text { августа } \\
\text { СПб., Большой театр }\end{array}$ & $\begin{array}{l}\text { Возвращение князя Пожарского в свое поместье. Дивертисмент. Хореографрия } \\
\text { Ш. Дидло, О. Пуаро }\end{array}$ \\
\hline 19 & $\begin{array}{l}\text { 1826, } 2 \text { октября } \\
\text { Москва }\end{array}$ & $\begin{array}{l}\text { Кавказский пленник, или Тень невесты. Балет по поэме А.С. Пушкина. Хореогра- } \\
\text { фия А.П. Глушковского }\end{array}$ \\
\hline 20 & $\begin{array}{l}\text { 1827, } 1 \text { июля } \\
\text { СПб., Каменно-островский } \\
\text { театр (открытие) }\end{array}$ & $\begin{array}{l}\text { Сельский праздник. Дивертисмент. Музыка К.А. Кавоса, аранжировка П.Ф. Тури- } \\
\text { ка и Д.А. Шелихова. Хореографрия Ш. Дидло, О. Пуаро }\end{array}$ \\
\hline 21 & $\begin{array}{l}1827 \\
\text { Москва, Большой театр }\end{array}$ & Праздник в Сибири. Дивертисмент \\
\hline & & Опера \\
\hline 1 & $\begin{array}{l}\text { 1805, } 5 \text { мая } \\
\text { СПб., Большой театр }\end{array}$ & $\begin{array}{l}\text { Князь-невидимка, или Личарда-волшебник. Волшебно-комическая опера. Пере- } \\
\text { вод текста Е. Лифранова }\end{array}$ \\
\hline 2 & $\begin{array}{l}\text { 1806, } 21 \text { января } \\
\text { СПб., Большой театр }\end{array}$ & Любовная почта. Комическая опера. Текст А.А. Шаховского \\
\hline 3 & $\begin{array}{l}\text { 1806, } 18 \text { апреля } \\
\text { СПб., Большой театр }\end{array}$ & $\begin{array}{l}\text { Беглец от своей невесты. Комическая опера. Текст А.А. Шаховского. Хореогра- } \\
\text { фия И.И. Вальберха }\end{array}$ \\
\hline 4 & $\begin{array}{l}\text { 1806, } 31 \text { декабря } \\
\text { СПб., Большой театр }\end{array}$ & $\begin{array}{l}\text { Илья-богатырь. Волшебная опера. Текст И.А. Крылова. Хореография И.И. Валь- } \\
\text { берха }\end{array}$ \\
\hline 5 & $\begin{array}{l}\text { 1808, } 15 \text { апреля } \\
\text { СПб., Большой театр }\end{array}$ & Три брата-горбуна. Комическая опера. Текст А.В. Лусницкого \\
\hline 6 & $\begin{array}{l}\text { 1812, } 15 \text { мая } \\
\text { СПб., Зимний дворец }\end{array}$ & Казак-стихотворец. Опера-водевиль. Текст А.А. Шаховского \\
\hline 7 & $\begin{array}{l}\text { 1815, } 17 \text { фревраля } \\
\text { СПб., Малый театр }\end{array}$ & Откупщик Бражкин, или Продажа села. Комическая опера. Текст А.А. Шаховского \\
\hline 8 & $\begin{array}{l}\text { 1815, } 19 \text { октября } \\
\text { СПб., Малый театр }\end{array}$ & Иван Сусанин. Опера. Текст А.А. Шаховского \\
\hline
\end{tabular}




\begin{tabular}{|c|c|c|}
\hline № & Дата, место премьеры & Название, авторы \\
\hline 9 & $\begin{array}{l}\text { 1818, } 25 \text { ноября } \\
\text { СПб., Большой театр }\end{array}$ & $\begin{array}{l}\text { Добрыня Никитич, или Страшный замок. Волшебная опера. Музыка К.А. Кавоса } \\
\text { и Ф. Антонолини. Хореография Ш. Дидло }\end{array}$ \\
\hline 10 & $\begin{array}{l}\text { 1820, } 22 \text { сентября } \\
\text { СПб., Большой театр }\end{array}$ & $\begin{array}{l}\text { Новая суматоха, или Женихи чужих невест. Комическая опера. Текст А.А. Шахов- } \\
\text { ского. Музыка К.А. Кавоса и Дж. Россини }\end{array}$ \\
\hline 11 & $\begin{array}{l}1821,1 \text { июня } \\
\text { СПб. }\end{array}$ & $\begin{array}{l}\text { Сюрпризы, или Всякая всячина и все в хлопотах. Опера-водевиль. Текст Н.В. Суш- } \\
\text { кова. Музыка К.А. Кавоса, А.Н. Верстовского, Ш.Ф. Ларона и [?] Корсакова }\end{array}$ \\
\hline 12 & $\begin{array}{l}\text { 1822, } 6 \text { ноября } \\
\text { СПб. }\end{array}$ & $\begin{array}{l}\text { Жар-птица, или Приключения Левсила-царевича. Волшебная опера. Текст Н. Язы- } \\
\text { коваа. Музыка К.А. Кавоса и Ф. Антонолини'. Хореографрия Ш. Дидло, О. Пуаро }\end{array}$ \\
\hline 13 & $\begin{array}{l}\text { 1822, } 29 \text { декабря } \\
\text { СПб. }\end{array}$ & $\begin{array}{l}\text { Светлана, или Сто лет в один день. Волшебная опера-баллада (по В.А. Жуков- } \\
\text { скому). Текст А.П. Вешнякова. Музыка Ш.С. Кателя и К.А. Кавоса. Хореографрия } \\
\text { Ш. Дидло }\end{array}$ \\
\hline 14 & $\begin{array}{l}\text { 1826, } 3 \text { октября } \\
\text { СПб. }\end{array}$ & $\begin{array}{l}\text { Мирослава, царица волшебниц, или Костер смерти. Опера. Музыка К.А. Кавоса, } \\
\text { Ф. Антонолини и Д.А. Шелихова. Хореографрия Ш. Дидло }\end{array}$ \\
\hline \multicolumn{3}{|r|}{ Драма } \\
\hline 1 & $\begin{array}{l}\text { 1823, } 19 \text { сентября } \\
\text { СПб. }\end{array}$ & $\begin{array}{l}\text { Александр и София, или Русские в Ливонии. «Национальная драма с пением». } \\
\text { Текст Р.М. Зотова }\end{array}$ \\
\hline 2 & $\begin{array}{l}\text { 1823, } 18 \text { октября } \\
\text { СПб. }\end{array}$ & $\begin{array}{l}\text { Сокол князя Ярослава Тверского, или Суженый на белом коне. «Русская быль». } \\
\text { Текст А.А. Шаховского. «Татарские игры с стрелянием из луков» Ш. Дидло }\end{array}$ \\
\hline 3 & 1825 & $\begin{array}{l}\text { Сон Светланы. «Волшебно-аллегорическое представление из баллады В.А. Жу- } \\
\text { ковского». Текст А.А. Шаховского }\end{array}$ \\
\hline 4 & $\begin{array}{l}1825,23 \text { апреля } \\
\text { Москва }\end{array}$ & $\begin{array}{l}\text { Финн. Волшебная комедия [из поэмы А.С. Пушкина «Руслан и Людмила»]. Текст } \\
\text { А.А. Шаховского. Балеты и игры А.П. Глушковского }\end{array}$ \\
\hline 5 & $\begin{array}{l}1825,28 \text { сентября } \\
\text { СПб. }\end{array}$ & $\begin{array}{l}\text { Керим-Гирей, или Крымский хан. Романтическая трилогия (по поэме А.С. Пушки- } \\
\text { на «Бахчисарайский фоонтан»). Текст А.А. Шаховского. Дивертисмент Ш. Дидло }\end{array}$ \\
\hline 6 & $\begin{array}{l}1825,19 \text { ноября } \\
\text { СПб. }\end{array}$ & $\begin{array}{l}\text { Аристофан, или Представление комедии «Всадники». Историческая комедия. } \\
\text { Текст А.А. Шаховского. Хореография Ш. Дидло }\end{array}$ \\
\hline 7 & $\begin{array}{l}1828,25 \text { мая } \\
\text { СПб. }\end{array}$ & $\begin{array}{l}\text { Радость молдаван', или Победа. Театральное представление. Музыка К.А. Кавоса } \\
\text { и [?] Эйзериха. Хореография Ш. Дидло, О. Пуаро }\end{array}$ \\
\hline 8 & $\begin{array}{l}\text { 1830, } 13 \text { октября } \\
\text { СПб. }\end{array}$ & $\begin{array}{l}\text { Праздник Столетия на Волге в } 1712 \text { году. Драматический эпилог. Текст А.А. Ша- } \\
\text { ховского }\end{array}$ \\
\hline
\end{tabular}

\footnotetext{
a А.А. Гозенпуд пришел к выводу, что в действительности текст написан М.С. Лебедевым [4, с. 142].

${ }^{\mathrm{b}}$ По мнению Ю.В. Келдыша, музыка балетных сцен оперы принадлежит Ф. Антонолини. Вывод сделан на основании ремарки в одной из сцен: «Хор де балет Антонолини» [4, с. 143].

c Е.Н. Дулова указывает на рукопись партитуры дивертисмента К.А. Кавоса «Лавровый венок, или Радость молдаван» [5, с. 101].
} 
«Ополчение, или Любовь к Отечеству», «Русские в Германии, или Следствие Любви к Отечеству» ${ }^{6}$, «Праздник в стане союзных армий при Монмартре», «Торжество России, или Русские в Париже» и другими.

Сюжеты таких балетов отражают этапы военных побед в русско-французской войне. Отдельные спектакли посвящены походам и победным торжествам казачьих войск («Казак в Лондоне», «Праздник донских казаков», «Казаки на Рейне») и раскрывают более узкий фольклорный срез - казачий фольклор.

Исследователи неоднократно отмечали простоту и бесхитростность сюжетов дивертисментных постановок, их невысокий художественный уровень, подчеркивая в то же время их популярность у публики.

Жанровой особенностью балетов-дивертисментов, в том числе авторства К.А. Кавоса, было сочетание признаков комической оперы, героической оперы спасения, балета и водевиля. Сценический диалог сменялся в них исполнением песенных куплетов, хоров и танцевальных номеров с выраженными этнографическими признаками.

В августе 1812 г. поставлен одноактный пантомимный балет-дивертисмент «с хорами и плясками» «Ополчение, или Любовь к Отечеству». А.А. Гозенпуд пишет о фабуле балета: «Отсутствие сценария позволяет лишь гипотетически восстановить общую схему сюжета. Действие, по-видимому, происходило в деревне во время праздника, возможно, свадебного сговора. Общее веселье прерывает известие о вторжении врага. <...> Добровольцы вступают в ряды ополченцев. Старики благословляют молодых воинов. <...> Прощание с уходящими на войну ополченцами, торжественное выступление в поход. <...> Можно предположить, что в центре сюжета находилась судьба влюбленных, разлучаемых войной» [7, с. 354]. Исследователи ранее отмечали, что балет построен на народных танцах, песнях и маршах, нередко основанных на русском и украинском фольклоре. Так А.А. Гозенпуд указывает на цитирование песни «Ивушка» ${ }^{7}$ в увертюре, женской арии «Милый мой, сердечный мой» и появление ее мотивов в других номерах балета, а также на воспроизве-

${ }^{6}$ А.М. Соколова пишет о трилогии балетов на музыку Кавоса, называя балет-дивертисмент «Ополчение, или Любовь к Отечеству», пантомимный балет «Русские в Германии, или Следствие Любви к Отечеству» и большой дивертисмент «Возвращение ополчения» (последний 1815 год). Однако в хронологической таблице той же книги среди спектаклей постановки 1815 г. указан лишь водевиль Ф. Антонолини «Возвращение ополчения в село Усердово» [6, с. $377 ; 8$, с. 73$]$.

7 Песня «Ивушка» существует в нескольких фольклорных вариантах. К сожалению, нам не удалось обнаружить образец из балета К.А. Кавоса ни в одном из сборников народных песен, выпущенных до момента создания балета. дение песни «Возле речки, возле мосту» в сольном мужском танце.

В действительности круг музыкальных цитат в произведении гораздо шире. Рукописную партитуру балета составляют 11 номеров, сохранившихся на разрозненных нотных листах ${ }^{8}$. В комплекте отсутствуют три номера (№ 3, 4, 7; обнаружены в репетиторе 9 балета). Не исключено, что они были изъяты для перенесения в другой балет. На страницах рукописи помечены имена исполнителей: указание «Le pas Mr. August» в № 3 (на тему песни «Возле речки») предполагало соло известного танцовщика, балетмейстера спектакля О. Пуаро, а ария с хором ${ }^{10}$ № 7 на тему плясовой песни исполнялась B.M. Самойловым [9, с. 216]. Главная тема увертюры, основанная на народной мелодии, сменяется темой наигрыша в исполнении флейт, сопровождаемых pizzicato ${ }^{11}$ скрипок, при этом струнная группа имитирует аккомпанемент балалайки. Интересно, что в оркестровом составе увертюры используется «турецкая» музыка ${ }^{12}$, нередко встречаемая в партитурах Кавоса. На русской лирической песне построен и первый номер балета. После марша № 4, звучащего, согласно ремарке нотного текста, «на театре», т. е. на сцене (March qui se joua sur le Theatro), композитор вводит мелодию «Марсельезы» ${ }^{13}$ в минорном ладу, вероятно, характеризующей в балете нашествие французских войск и последующее поражение. В № 11, снова исполняемом струнными pizzicato, угадывается танцевальная мелодия «Казачок». Неоднократно использован прием повтора музыкального материала. Так в № 12 использован материал № 10, а после № 13 (полонез) внесена рукописная помета на французском языке: «Говорят, а затем следует № 12» («L’On parle a puis le № 12»). Апофеозом спектакля, согласно тексту пометы в партитуре, становится «Хор из [оперы] “Илья-богатырь”, завершающий балет» (Choeur d'Ilya Bogatyr avec quoi finit le Ballet).

8 Партитура находится в Нотной библиотеке Мариинского театра (ЦМБ). Автор выражает признательность сотрудникам библиотеки за предоставленные материалы.

9 Переложение партитуры для одной, двух скрипок или для скрипки с солирующим инструментом для проведения репетиций с танцовщиками.

${ }^{10}$ В ремарке имя солиста указано неразборчиво: «Air de Mr. Samojloff [?] avec le Choeur».

11 Прием игры на струнном инструменте, при котором исполнитель играет на струне не смычком, а щипком, отрывисто.

12 «Турецкая» (Musique Turque) или «янычарская» музыка - изначально оркестр, нередко военный, состоящий из духовых и ударных инструментов. В XVIII в. использовался в партитурах для создания экзотического и курьезного колоритов, содержал видовые духовые инструменты (флейты пикколо, рожки, свирели, волынки) и ударные (барабаны, тарелки, треугольник, литавры).

13 Песня Великой французской революции, ставшая позднее гимном страны. В музыкальных сочинениях использовалась композиторами как символ появления французских войск. 


\section{Хоры из оперы «Илья-Богатырь»}

I действие,
явление 4

III действие,
явление последнее
Хор
Вы летите к нам, забавы,
Радость, будь во всех сердцах.
Гром побед и нашей славы,
В ратных ты греми полях!

Финальный номер представляет собой автоцитату Кавоса из произведения на «русский» сказочно-былинный сюжет. Его волшебная опера в трех действиях «Илья-богатырь» написана на либретто И.А. Крылова и поставлена в 1806 году ${ }^{14}$. Балеты в опере, как и в дивертисменте «Любовь к Отечеству», сочинены И.И. Вальберхом. Хор выполняет в опере очень важную действенную и организующую функцию, появляясь в разном обличии (народ, разбойники, ду́хи). Вокальные партии хоров не сохранились. По содержанию к финалу балета Кавоса могут быть отнесены только три хора из «Ильи-богатыря», призывающие к сражению и славящие победителей [10] (см. табл. 2).

Вместе с тем известно, что к постановке оперы «Илья-богатырь» 1812 г. был специально написан еще один хор-эпилог, завершающий оперу, на текст «Победа! Победа русскому герою! Врагам России смерть и стыд!». По всей видимости, этот хор, ставший своеобразным гимном военного времени, был помещен Кавосом в балет «Любовь к Отечеству» [11, с. 258].

Хоровой номер из оперы стал заключительным аккордом в финале дивертисмента, призванным укрепить чувство патриотического долга слушателей перед Родиной: «одно пошевеление знамени с надписью за Отечество, доводило зрителей до исступления. От сильного сердечного чувствования все то плакали, то кричали, или рукоплескали. ...Некоторые из зрителей, вышед из театра, на другой день бежали прямо в комитет записываться в ряды ополчения... Незабвенное, достопамятное время!» $[12$, с. 80$]$.

Дивертисмент «Сельский праздник» на музыку К.А. Кавоса был приурочен к открытию санкт-петербургского Каменноостровского театра в 1827 году ${ }^{15}$.

${ }^{14}$ Исследователи отмечают сюжетные пересечения оперы с поэмой «Руслан и Людмила» А.С. Пушкина и схожие драматургические ситуации в опере М.И. Глинки.

15 Е.Н. Дулова датирует балет 1818 г., у М.В. Борисоглебского другая дата постановки спектакля с тем же названием: «Сельский праздник. Большой дивертисмент, соч[инения] Огюста Пуаро, муз[ыка] разных авторов. 1828, 26/I». В Хронологической таблице в 5 томе «Истории русской му-
Хореография спектакля принадлежала Ш. Дидло и О. Пуаро. Над музыкальным материалом Кавос работал совместно с П.Ф. Туриком и Д.А. Шелиховым. Партитура балета ${ }^{16}$ сохранилась в виде 12 разрозненных номеров ${ }^{17}$, при этом пять номеров, вероятно, заимствованы из комплекта к другому спектаклю. Нотные тексты содержат пометы, подчеркивающие фольклорные истоки балетных композиций: «Козак», «Masuruе» (Мазурка), «Цызанская пляска из Лефорта», «Русская пляска во поле беріоза стояла». Достоверно удалось установить цитирование песни «Во поле береза стояла» в № 6; идентификация мелодий казачьей, цыганской плясок и мазурки требует специального поиска. Музыка других номеров также близка народным танцевальным мелодиям, не исключены цитаты. Фабула спектакля не установлена, но она, определенно, опиралась на бытовой комический сюжет, вовлекая публику в атмосферу праздничного веселья.

В музыке К.А. Кавоса к драме А.А. Шаховского в четырех действиях «Сокол князя Ярослава Тверского, или Суженый на белом коне» (1823) балетные сцены, поставленные знаменитым Ш. Дидло, выполняют особую роль в воплощении русского сюжета. Драма получила авторское жанровое определение «русская быль». Сохранились интереснейшие источники - комплект оркестровых голосов, хоровая партитура ${ }^{18}$ и либретто [15] - по которым можно составить представление о спектакле. Так на титульном листе издания 1823 г. указано, что пьеса содержала песни, хоры, воинские потехи, танцы, игры, борьбу.

зыки» указано, что дивертисмент «Сельский праздник» был поставлен 1 июля 1827 г. на открытие санкт-петербургского Каменноостровского театра [5, с. 211; 13, с. 288; 14, с. 467].

16 Партитура находится в Нотной библиотеке Мариинского театра.

17 Помета на первой странице партитуры: «Divertissement la Fête de la Cinquantaine par Mr. Didelot» («Дивертисмент на празднование пятидесятилетия, сочинения господина Дидло»).

${ }^{18}$ Кавос К.А. Сокол князя Ярослава Тверского, или Суженый на белом коне. Русская быль в 4-х действиях. Партитура и оркестровые партии / Всероссийское музейное объединение музыкальной культуры им. М.И. Глинки. Ф. 165. № 773. П. № 4336. 
Действие «Сокола» происходит на Руси в XIII в. и раскрывает романтичную историю встречи великого князя Ярослава с будущей невестой Ксенией. Драма основана на реальных исторических событиях. Ксения просватана за Вассиана, сына Ратибора, с которым враждовал ее отец. Во снах она видит другого жениха - всадника на белом коне. Накануне ее свадьбы Ярослав отправляется на соколиную охоту, оседлав белого коня. Сокол, оказавшись на свободе, неожиданно приводит князя к дому Ксении, где молодые обретают друг друга.

Для спектакля К.А. Кавосом написаны несколько музыкальных номеров: хор и две песни I действия, два хора и музыка пантомимы II действия, песня Наташи III действия. Все хоры и песни драмы опираются на фольклорные источники - тексты и мелодии. В хоре крестьян «Не вздымайся Волга матушка, не шумите ветры буйные», в песне Наташи с хором «Отчего ты рассиялося солнце красное в золотых лучах» и песнях «Не стружек ${ }^{19}$ на водах паруском мелькает», «Ах, всходи ты солнце красное» задействованы сюжетные мотивы и речевые обороты известных русских песен (в том числе «Не бушуйте, ветры буйные», «Ты взойди, солнце красное») в их авторской интерпретации А.А. Шаховского. Примером может быть назван хор «Не вздымайся Волга матушка», перенесенный, как удалось установить, А.А. Шаховским и К.А. Кавосом вместе с увертюрой из их совместной оперы «Иван Сусанин» в партитуру «Сокола».

«Иван Сусанин» (1815) - первая русская историко-патриотическая опера, которая получила широкую популярность у публики и возобновлялась в течение долгого времени. В увертюре оперы Кавос выдвигает антитезу «свое - чужое», характеризуя русских героев вокальными темами, близкими к фольклору, а образ поляков строит на инструментальном типе изложения ${ }^{20}$. Хор «Не бушуйте ветры буйные» перешел из оперы в драму со значительными изменениями. В каждом случае народная мелодия (композитор излагает четыре такта одного из вариантов песни «Не бушуйте, ветры буйные») получает полифоническое развитие, однако в драме форма значительно сокращена. А.А. Шаховской также предлагает обновленный вариант текста:

\section{«Сусанин»:}

\section{«Сокол»:}

Не бушуйте ветры буйные, Не вздымайся Волга матушка, Не сносите листа желтаго Не шумите ветры буйные;

С леса частого матерых дубов! Погоди ты осень темная, Дай работушки окончить нам.

\footnotetext{
19 Лодка, челн.

20 В дальнейшем этим принципом воспользуется М.И. Глинка в опере «Жизнь за царя».
}

Противопоставление национальных характеристик в «Соколе» раскрывается через балетную сцену второго действия. Князь Ярослав объявляет турнир среди русских, немецких и татарских воинов в присутствии иноземных послов. Батальная сцена решена через пантомиму, изображающую сражения и игры. Программа балета раскрыта в ремарках текста А.А. Шаховского: «Игры начинаются сперва стреляют татарки на бегу, когда одна попадет в цель, то все кричат: ура! и она из Княжих рук получает ожерелье - потом начинается борьба, Чешко отличается и, подшибя под ногу лучшаго Татарского борца, кричит». <...> «Сражение на булавах и мечах начинается, Магнус, Вассиан, Чевгу и Банши остаются победителями. Магнус, положа Татар и Новгородцов, остается победителем, но Банши на него нападает - Вассиан повергает Чевгу» [15, с. 60-61].

Сцена составлена из трех номеров. Первый из них открывает «татарской хор», переходящий в «балет» ${ }^{21}$. Хор восхваляет великого хана Магну-Тимура:

\section{Да здравствует наш хан Вселенной покоритель \\ И всех подлунных стран Могучий повелитель.}

Звучание хора сурово и враждебно. Варварский колорит подчеркнут введением в оркестр медной духовой группы и «турецкой музыки». Хор продолжается «татарскими играми» - пантомимным разделом с агрессивно-угловатыми чертами мелодии. Два последующих номера выводят музыкальный материал на типичные образцы батальных сцен, но с сохранением острых пунктирных ритмов, акцентов, мелодических скачков. Так пантомимная сцена сражения с чужестранцами позволила композитору противопоставить национальным героям драмы (Ярослав, Чешко, Юрий, новгородские богатыри) образы их исторических противников (татарские богатыри, немецкие крестоносцы).

В целом показательна многократная вовлеченность балетных эпизодов в российские оперные, драматические спектакли данного периода, появление самостоятельных балетных спектаклей национального содержания, получивших восторженную поддержку общества и проживших долгую жизнь на сцене. Немалую роль в этом процессе сыграл русский композитор итальянского происхождения Катерино Альбертович Кавос, чьи потомки в нескольких поколениях верой и правдой служили русскому Отечеству.

\section{Список источников}

1. Максимова A.E. «Ахридеич» - опера-сказка Э. Ванжуры на либретто Екатерины II // Opera Musocologica. 2012. № 4 [14]. C. 25-73.

\footnotetext{
${ }^{21}$ Ремарки из партии первой скрипки.
} 
2. Ковалева Е.А., Максимова А.Е. Историческое представление «Начальное управление Олега» (1790) // Музыковедение. 2012. № 12. С. 7-22.

3. Штелин Я.Я. Музыка и балет в России XVIII века. Санкт-Петербург : Союз художников, 2002. 318 с.

4. Келдыш Ю.В. К.А. Кавос и русская опера // История русской музыки : в 10 т. Т. 4. Москва : Музыка, 1986. $416 \mathrm{c.}$

5. Дулова Е.Н. Балетный жанр как музыкальный феномен (русская традиция конца XVIII - начала XX века). Минск : Четыре четверти, 1999. 378 с.

6. Корженьяни Т.В. Хронологическая таблица // История русской музыки : в 10 т. Т. 4. Москва : Музыка, 1986. $416 \mathrm{c}$.

7. Гозенпуд А.А. Музыкальный театр в России. От истоков до Глинки. Ленинград : Государственное музыкальное издательство, 1959. 782 с.

8. Соколова А.М. Балетный театр // История русской музыки : в 10 т. Т. 4. Москва : Музыка, 1986. 416 с.

9. Арапов П.Н. Летопись русского театра. Санкт-Петербург : Типография Н. Триблена и комп., 1861. 387 c.

10. Крылов И.А. Илья-богатырь. Волшебная опера в 4-х действиях. Либретто // Полное собрание сочинений : в 3 т. / ред. текста и примечания Н.Л. Бродского. Москва : Государственное издательство художественной литературы, 1946. Т. 2 [Драматургия]. С. $491-554$.
11. Левашева О.Е., Келдыш Ю.В., Кандинский А.И. История русской музыки. Т. 1. От древнейших времен до середины XIX в. : учебн. для муз. вузов. 3-е изд., доп. Москва : Музыка, 1980. 623 с.

12. Штейнгель В.И. Записки касательно составления и самаго похода санктпетербургскаго ополчения против врагов отечества, в 1812 и 1813 годах, с кратким обозрением всех произшествий, во время бедствия и спасения нашего отечества случившихся, и с подробным описанием осады и взятия Данцига / писанныя Фл. к. лейт. Б.В. Шт. Санкт-Петербург : Типография В. Плавильщикова, 1814-1815. Ч. 1. 241 с.

13. Борисоглебский М.В. Прошлое балетного отделения Петербургского театрального училища. Материалы по истории русского балета. Т. 2. Ленинград : Ленинградское государственное хореографическое училище, 1939.356 с.

14. Корженьяни Т.В. Хронологическая таблица // История русской музыки : в 10 т. Т. 5. Москва : Музыка, 1988. С. $458-509$.

15. Шаховской А.А. Сокол князя Ярослава Тверского, или Суженый на белом коне : русская быль в 4-х действиях, с песнями, хорами, воинскими потехами, танцами, играми, борьбой и большим спектаклем, музыка сочинения господина Кавоса / Отдел редких книг и рукописей Научной библиотеки МГУ им. М.В. Ломоносова. Санкт-Петербург : Типография Императорских театров, 1823.129 с.

\section{THE RUSSIAN SUBJECT IN THE BALLET WORKS OF CATTERINO CAVOS}

\section{ALEKSANDRA E. MAKSIMOVA}

Tchaikovsky Moscow State Conservatory, 13/6, Bolshaya Nikitskaya St., Moscow, 125009, Russia

E-mail: alexmaximova@mail.ru

\begin{abstract}
The article is devoted to the ballet works created by the Italian composer C.A. Cavos in Russia. Over 50 theatrical works of the composer are almost unknown, but they make a significant contribution to the national culture. The study is conducted on the basis of unpublished sources from the archives of St. Petersburg and Moscow. The article traces the history of the national subjects of Russian musical professional theater, from the time of Catherine II to the first quarter of the 19th century. There is reviewed the problem of "Russian" subject in the operas, ballets, drama plays with Cavos's music. A list of those works is compiled, which demonstrates that the composer regularly collaborated with the writer A.A. Shakhovskoy and choreographer Ch. Didelot. The review includes the historical, common, and fairy-magical subjects. The stylistic features of
\end{abstract}

the works are noted (including their reliance on folk material), by the example of Cavos's ballet divertissements " $M i$ litia, or Love for the Fatherland", "Village Festival", music to Shakhovskoy's drama "Falcon of Prince Yaroslav of Tver, or the Betrothed on a White Horse".

Key words: Russia, C.A. Cavos, history, theater, ballet, divertissement, opera, drama, music, folklore.

Citation: Maksimova A.E. The Russian Subject in the Ballet Works of Catterino Cavos, Observatory of Culture, 2017, vol. 14, no. 2, pp. 198-207.

\section{Acknowledgements}

This article is written with the support of the Russian Foundation for Basic Research, project no. 16-0400473.

\section{References}

1. Maksimova A.E. "Akhrideich" - opera-skazka E. Vanzhury na libretto Ekateriny II [Arnošt Vančura's Opéra Féerie "Arkhideich" to Words by Catherine II], Opera Musocologica, 2012, no. 4 [14], pp. 25-73.

2. Kovaleva E.A., Maksimova A.E. Istoricheskoe predstavlenie "Nachal'noe upravlenie Olega" (1790) [The Historical Performance “The Early Reign of Oleg” (1790)], Muzykovedenie [Musicology], 2012, no. 12, pp. 7-22. 
3. Shtelin Ya.Ya. Muzyka i balet v Rossii XVIII veka [Music and Ballet in Russia of the 18th Century]. St. Petersburg, Soyuz Khudozhnikov Publ., 2002, 318 p.

4. Keldysh Yu.V. K.A. Kavos i russkaya opera [C.A. Cavos and the Russian Opera], Istoriya russkoi muzyki: $v 10 t$. [The History of Russian Music: in 10 Volumes], vol. 4. Moscow, Muzyka Publ., 1986, 416 p.

5. Dulova E.N. Baletnyi zhanr kak muzykal'nyi fenomen (russkaya traditsiya kontsa XVIII - nachala XX veka) [The Ballet Genre as a Musical Phenomenon (the Russian Tradition of the Late 18th - Early 20th Century)]. Minsk, Chetyre Chetverti Publ., 1999, 378 p.

6. Korzhenyants T.V. Khronologicheskaya tablitsa [Chronological Table], Istoriya russkoi muzyki: $v 10 t$. [The History of Russian Music: in 10 Volumes], vol. 4. Moscow, Muzyka Publ., 1986, 416 p.

7. Gozenpud A.A. Muzykal'nyi teatr v Rossii. Ot istokov do Glinki [The Musical Theater in Russia. From its Origins to Glinka]. Leningrad, Gosudarstvennoe Muzykal'noe Publ., 1959, $782 \mathrm{p}$.

8. Sokolova A.M. Baletnyi teatr [Ballet Theater], Istoriya russkoi muzyki: $v 10 t$. [The History of Russian Music: in 10 Volumes], vol. 4. Moscow, Muzyka Publ., 1986, $416 \mathrm{p}$.

9. Arapov P.N. Letopis' russkogo teatra [The Chronicle of Russian Theater]. St. Petersburg, N. Triblena i Kompanii Publ., 1861, 387 p.

10. Krylov I.A. Il'ya-bogatyr'. Volshebnaya opera v 4-kh deistviyakh. Libretto [Ilya the Bogatyr. The Opera in 4 Acts. Libretto], Polnoe sobranie sochinenii: $v 3 t$. [Complete
Works: in 3 Volumes]. Moscow, Gosudarstvennoe Izdatel'stvo Khudozhestvennoi Literatury Publ., 1946, vol. 2, pp. 491-554.

11. Levasheva O.E., Keldysh Yu.V., Kandinsky A.I. Istoriya russkoi muzyki. T. 1. Ot drevneishikh vremen do serediny XIX v. [The History of Russian Music. Vol. 1. From the Ancient Times to the Middle of the 19th Century]. Moscow, Muzyka Publ., 1980, 623 p.

12. Shteingel V.I. Notes Regarding the Campaign and its Preparation of the St. Petersburg Militia against the Enemies of the Fatherland, in 1812 and 1813, with a Brief Overview of all Incidents that Occurred during the Disaster and Salvation of our Fatherland, and with a Detailed Description of the Siege and Capture of Danzig. St. Petersburg, V. Plavil'shchikova Publ., 1814-1815, part 1, 241 p. (in Russ.).

13. Borisoglebsky M.V. The Past of the Ballet Department of the St. Petersburg Theatre School. The Materials on the History of Russian Ballet, vol. 2. Leningrad, Leningradskoe Gosudarstvennoe Khoreograficheskoe Uchilishche Publ., 1939, 356 p. (in Russ.).

14. Korzhenyants T.V. Khronologicheskaya tablitsa [Chronological Table], Istoriya russkoi muzyki: $v 10 t$. [The History of Russian Music: in 10 Volumes], vol. 5. Moscow, Muzyka Publ., 1988, pp. 458-509.

15. Shakhovskoy A.A. The Falcon of Prince Yaroslav of Tver, or the Betrothed on a White Horse: the Russian True Story in 4 Acts, with Songs, Choirs, Military Fun, Dancing, Games, Wrestling, and a Big Play; the Music Is Composed by Mr. Kavos. St. Petersburg, Imperatorskikh Teatrov Publ., 1823, 129 p. (in Russ.).

\section{Первый съезд Ассамблеи народов Евразии Москва, 27-29 мая 2017 г.}

Наряду с развитием взаимовыгодных экономических связей между государствами, важными аспектами являются расширение культурно-гуманитарного сотрудничества, развитие взаимодействия неправительственных организаций во имя укрепления доверия, мира и согласия между народами на евразийском пространстве.

Среди тематических площадок Съезда:

- Гуманитарные проекты и образовательное сотрудничество на евразийском пространстве;

- Потенциал сетевой научно-экспертной евразийской кооперации;

- Роль русского языка на евразийском пространстве;

- Миротворческий потенциал науки, образования и традиционной культуры;

- Международное культурное сотрудничество и общественная дипломатия в современном мире: новые вызовы и возможности;

- Этнокультурный диалог на евразийском пространстве;

- Родовая культура в межнациональном диалоге;

- Культурный диалог на евразийском кинопространстве.

Контакты: +7 (495) 774-82-82, info@eurasia-congress.org

Регистрация участников на сайте: eurasia-congress.org 